\title{
Fuzzy Inference System Based Prediction of Electrical Discharge Machining Quality
}

\author{
MARIN P. GOSTIMIROVIĆ, University of Novi Sad, \\ Faculty of Technical Sciences, Novi Sad \\ DRAGAN Đ. RODIĆ, University of Novi Sad, \\ Faculty of Technical Sciences, Novi Sad \\ MILENKO LJ. SEKULIĆ, University of Novi Sad, \\ Faculty of Technical Sciences, Novi Sad
}

Original scientific paper

UDC: 621.7

\begin{abstract}
Quality and productivity are two most important performances of electrical discharge machining $(E D M)$. This paper presents the application of a fuzzy inference system (FIS) for prediction of machining quality in the EDM process. Specifically, the FIS conducted modeling of geometrical accuracy and surface finish of EDM machined parts. With the fuzzy inference system model, the input variables are discharge current and pulse duration, while the output parameters are gap distance between the electrodes and surface roughness of the workpiece. The performance of the proposed FIS provides a more effective selection of the EDM input values, which leads to better machining conditions and quality of the final product. The fuzzy inference system based modeling of the EDM process showed a very good agreement compared to the experimental data.
\end{abstract}

Key words: EDM process, discharge parameters, gap distance, surface roughness, FIS model

\section{INTRODUCTION}

Over the past few years, modern manufacturing industry is increasingly turning to the use of difficultto-process materials with unique mechanical, physicochemical and functional properties [1-3]. Traditional machining of these advanced materials such as metal alloys used in automotive, medical, aerospace, military and tool industries is usually accompanied with low productivity and poor machining quality. Therefore, non-conventional machining methods are more often employed to produce different industrial parts from difficult-to-process materials.

Electrical discharge machining $(\mathrm{EDM})$ is one of the most widely used non-conventional manufacturing process which is applied for machining electrically conductive workpiece materials, regardless of their mechanical and metallurgical properties. It is primarily used for processing of complex geometry shapes and other high quality products with lots of fragile and

Author's address: Marin Gostimirović, University of Novi Sad, Faculty of Technical Sciences, Novi Sad, Trg

Dositeja Obradovića 6

e-mail: maring@uns.ac.rs

Paper received: 31.07.2020.

Paper accepted: 19.05.2021. small parts [4].

The electrical discharge machining is a complex process based on the material removal as a consequence of the development of thermal electrical energy between the tool electrode and the workpiece being submerged in a dielectric fluid. The extremely high temperature developed in the working zone causes melting and vaporization of a certain quantity of the workpiece material. However, if the workpiece material removal is a positive effect, this process faces some problems, such as low efficiency and quality of machining.

In the modern manufacturing, the machining quality is one of the most important requirements in processing, as it is considered an index of the functionality of the product. In the electrical discharge machining, to achieve good machining quality, it is important to select processing parameters and their levels cautiously in order to realize the best outcome of the process $[5,6]$. Generally, the desired processing parameters are determined based on the literature review, experience in the field or experiment results. However, such a choice of EDM parameters is an ill-defined problem because it generally relies on uncertain values which are not easy to strictly define [7]. Therefore, to know electrical discharge machining quality, it is necessary 
to employ models making it possible to do predictions in function of the EDM parameters. In previous years, modeling and prediction of EDM machining quality by soft computing approach plays a leading role in the manufacturing process $[8,9]$.

Soft computing, especially fuzzy logic set theory can certainly be applied to processes like EDM in which the knowledge and experiences of experts play a very important role. A lot of fuzzy models were developed and used for the selection of electrical discharge machining process parameters [10-13].

Regarding the EDM machining quality, Tsai and Wang [14] established seven models in order to predict the surface finish of the workpiece based upon the neuro-fuzzy approach. Lin and Lin [15] introduced the use of grey-fuzzy Taguchi method for the modeling of surface roughness in the EDM process with the multiple responses set. Caydas et al. [16] developed an adaptive neuro-fuzzy inference system (ANFIS) model for the prediction of surface integrity realized as a function of the EDM process parameters. Suganthi et al. [17] proposed ANFIS model to the prediction of multiple processing quality responses in micro-EDM operations. Gostimirovic et al. [18] modeled the workpiece surface roughness after EDM by using the genetic programming method. It was observed that all soft computing techniques produce a more reliable machining quality prediction under different process conditions.

From the review of literature, it is observed that the fuzzy logic approach has found wide applications in modeling and optimization process parameters in the electrical discharge machining.

However, it is seen that attempts to study the effect of EDM processing characteristics on the machining quality are still scarce. In that sense, to improve the accuracy of the machining quality prediction, this study uses a more sophisticated learning tool called fuzzy inference system.

The presented FIS model establishes the good relationship between the EDM input electrical discharge parameters (discharge current and pulse duration) and the output machining quality performance (gap distance and surface roughness).

\section{FIS MODEL OF EDM PROCESS}

Fuzzy inference system (FIS) is a soft computing method that uses fuzzy set qualitative comparative analysis to map inputs to outputs in the case of fuzzy classification, without using a precise quantitative model. The FIS is very efficient tool to help make decision on the complex uncertain processes by incorporating expert knowledge and experience, just such as the engineering problems [19].
The elementary structure of the fuzzy inference system is composed of an if-then rule base which consists of a selection of fuzzy sets, a database of the fuzzy membership functions used in the fuzzy inference system and a fuzzy reasoning mechanism that performs the inference procedure for the given inputs $[20,21]$. In FIS modeling, the consequent parameters of the if-then rules define a fuzzy field of the input and the corresponding output. There are several types of fuzzy inference systems [22].

Mamdani FIS is the most used method because of the relatively simple structure and the interpretability of the rule-base [23]. The advantages of the Mamdani approach are intuitive nature and suitability to human interaction. Sugeno FIS is more flexible because the output is a function of the input [24]. The benefits of the Sugeno approach are good mathematical analysis and computational efficiency. In terms of use, the Mamdani type is suitable for use with a small number of training data and the Sugeno vice versa. Other types of the FIS are not popular approaches because they are not as transparent.

In this research, the Mamdani fuzzy inference system is used. Generally, the Mamdani FIS architecture at a system with one input and one output by a conditional knowledge base $\mathrm{R}$ with $\mathrm{n}$ rules [23]:

$$
R=\{R 1, R 2, \ldots R n\}
$$

contains irreparable if-then rules of the form:

$$
\text { IF } X \text { is } A \text {, THEN } Y \text { is } B
$$

where $A$ and $B$ are the fuzzy set of linguistic variables for the input-output $X$ and $Y$, respectively.

In this particular instance, the fuzzy inference system of the EDM machining quality for two inputs (discharge current and pulse duration) and one output (gap distance or surface roughness) is reported as a multi-input single-output (MISO) fuzzy inference system:

$$
\begin{aligned}
& R_{i} \text { :IF I is } A_{i} \text { and } t \text { is } B_{i} \text { THEN } a \text { is } C_{i} \\
& \text { or } \\
& R_{i} \text { :IF I is } A_{i} \text { and } t \text { is } B_{i} \text { THEN } R_{a} \text { is } C_{i}
\end{aligned}
$$

where $R_{i}$ is the fuzzy rule base, $I$ is the discharge current, $t$ is the pulse duration, $a$ is the gap distance, $R_{a}$ is the surface roughness and $\left(A_{i}, B_{i}, C_{i}\right)$ are the linguistic fuzzy variables.

Fig. 1 shows the design of a fuzzy inference system for modeling the electrical discharge machining quality. The presented design of the FIS model of the EDM process is arranged into several phases. The selection of input-output variables and their levels is the first phase. The second phase was creating a fuzzy 
multi-input single-output system. The stages of fuzzification and the appropriate membership functions for each variable are defined. From the wide range of membership functions, in this case for modeling the machining quality, the symmetric Gaussian membership function is used. Also, the fuzzy rules and procedure of defuzzification are generated. The selection of method for calculating crisp output values and validation tests to verify the results are carried out in the final phase.

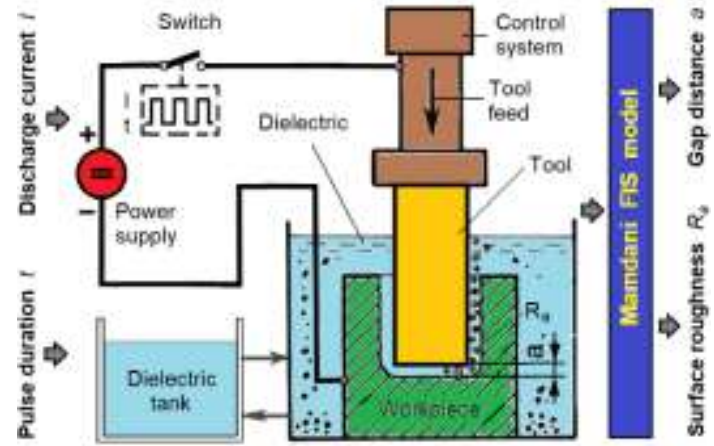

Figure 1 - FIS model of machining quality in EDM process

Fuzzy expressions for input variables (discharge current in the range of 1 to $50 \mathrm{~A}$ and pulse duration in the range of 1 to $100 \mu \mathrm{s}$ ) are divided into seven and eight sets, ranging from lowest to highest membership functions as shown in Figure 2.
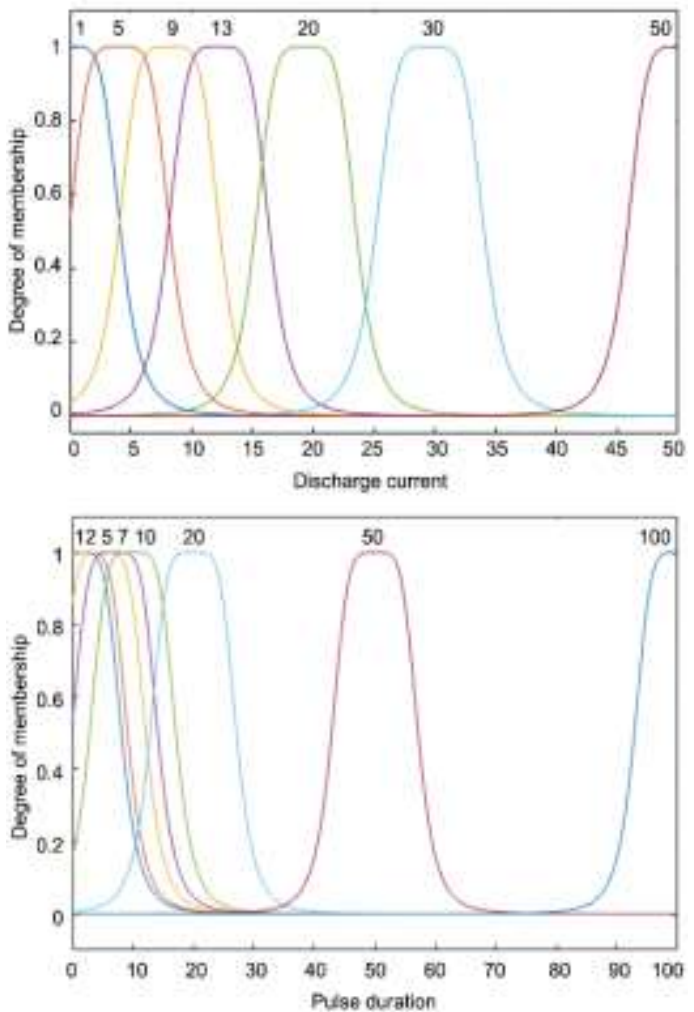

Figure 2 - Membership functions of input variables: discharge current and pulse duration
On the other hand, the number of membership functions used to the outputs response is seven for the gap distance (order from $\mathrm{A}$ to $\mathrm{G}$ ) and eight for the surface roughness (order from $A$ to $H$ ), respectively, Figure 3. The outputs response of the FIS structure can be reviewed only in fuzzy values which must be defuzzified.

\section{EXPERIMENTAL PROCEDURES}

Experimental investigations were conducted on the CNC die sinking EDM machine, max working current $60 \mathrm{~A}$. The hydrocarbon oil was used as dielectric fluid with the natural flushing process. The workpiece material used in the experiment was high alloy cold work tool steel, AISI O2 $(0.9 \% \mathrm{C}, 2 \% \mathrm{Mn}$, $0.3 \% \mathrm{Cr}$, and $0.2 \% \mathrm{~V}$ ), with hardness $62 \mathrm{HRC}$. The tool was made of fine grain isostatic graphite electrode, $20 \times 10 \mathrm{~mm}$ constant cross-section. The setup of the experiment is shown in Fig. 4.
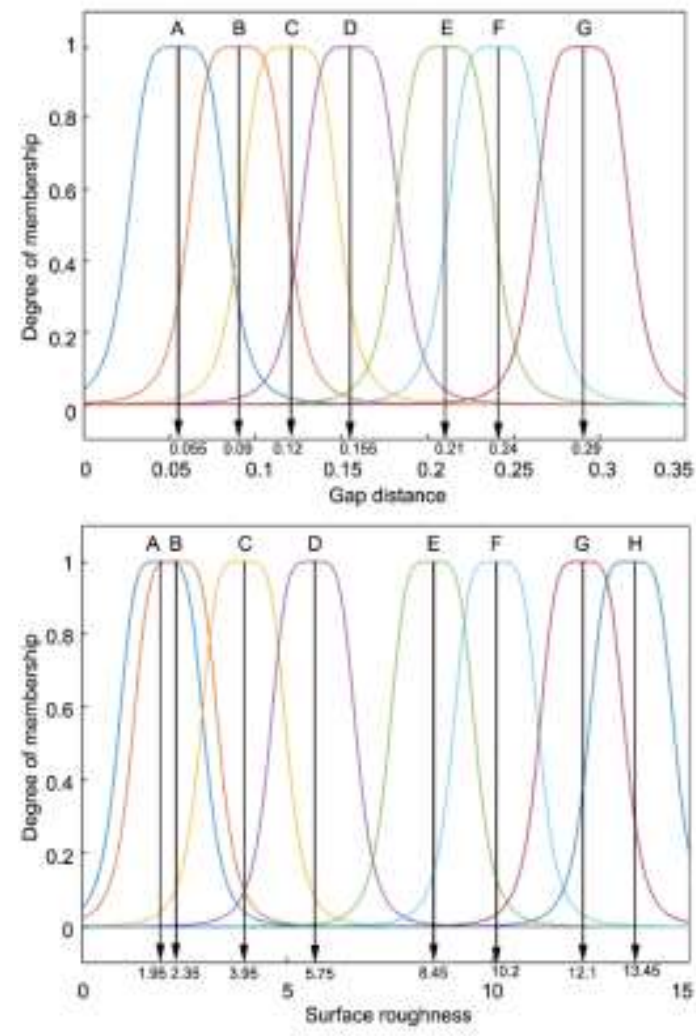

Figure 3 - Membership functions of output variables: gap distance and surface roughness

The machining conditions included variable electrical discharge parameters. The discharge current was varied in the range $I=1$ to $50 \mathrm{~A}$, while the pulse duration was varied in the interval $t=1$ to $100 \mu \mathrm{s}$ according to the set current. The rest of the processing parameters were held constant, by the manufacturer's recommendations (open gap voltage $U_{o}=100 \mathrm{~V}$, duty factor $\tau=0.8$ and positive electrode polarity). 
EDM machining quality was assessed across geometrical accuracy and surface finish. The geometrical accuracy was monitored through the change of the gap distance $a$ between the workpiece and the tool electrode. The gap distance was calculated as the half of difference between the tool and workpiece contour dimensions.

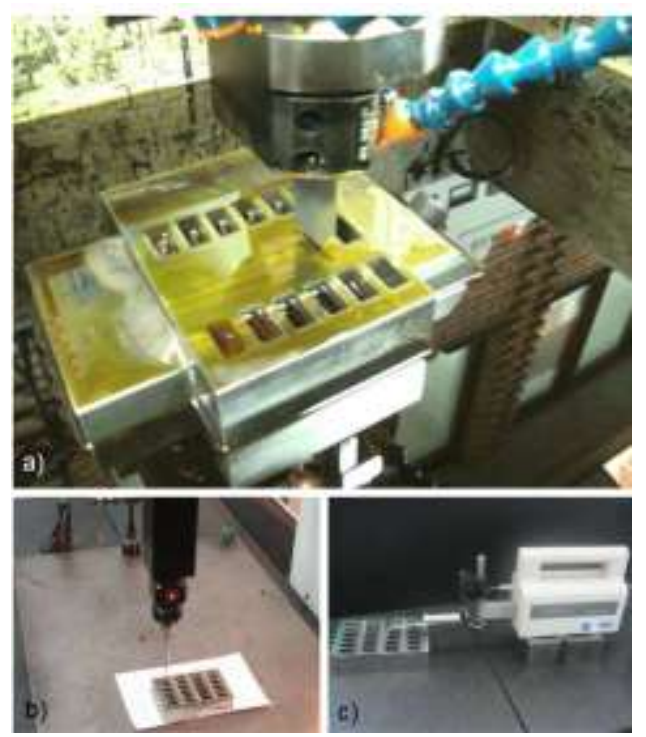

Figure 4 - a) Experimental setting, b) Measuring the gap distance, c) Measuring the surface roughness
Measurements were conducted using the Global CNC Coordinate Measurement Machine, Figure 4b. The surface finish was assessed by measuring surface roughness $R_{a}$ (ISO 4287).

The surface profilometer Carl Zeiss model Surfcom $130 \mathrm{~A}$ was used to measure the arithmetic average surface roughness during EDM, Fig.ure 4c.

\section{RESULTS AND ANALYSIS}

In the EDM machining, electrical discharge parameters that may affect the machining quality are the discharge current and pulse duration, where higher or lower values of these parameters may decrease or increase the electrode gap distance and surface roughness of the workpiece.

Table 1 shows the results of experimental researches for the selected machining characteristic. The results of investigation show a less increase of the gap distance and surface roughness with the increase of pulse duration, while the discharge current has a more pronounced influence on the machining quality performance. As already mentioned, the fuzzy inference system modeling was used to predict electrical discharge machining quality and to verify the agreement of the experimental results. The results of the FIS model are given in the previous Table 1, at the same time with the obtained experimental results.

Table 1. The results of experimental and FIS model

\begin{tabular}{|c|c|c|c|c|c|c|}
\hline \multirow{3}{*}{$\begin{array}{l}\text { Level } \\
\left(\mathrm{N}^{\circ}\right)\end{array}$} & \multicolumn{2}{|c|}{ Machining conditions } & \multicolumn{4}{|c|}{ Machining quality performance } \\
\hline & \multirow{2}{*}{$\begin{array}{l}\begin{array}{l}\text { Discharge } \\
\text { current }\end{array} \\
I(\mathrm{~A}) \\
\end{array}$} & \multirow{2}{*}{$\begin{array}{l}\text { Pulse duration } \\
T(\mu \mathrm{s})\end{array}$} & \multicolumn{2}{|c|}{ Gap distance } & \multicolumn{2}{|c|}{ Surface roughness } \\
\hline & & & $a_{E X P}(\mathrm{~mm})$ & $a_{F I S}(\mathrm{~mm})$ & $R_{a E X P}(\mu \mathrm{m})$ & $R_{a F I S}(\mu \mathrm{m})$ \\
\hline \multirow{3}{*}{$\begin{array}{l}1.1 \\
1.2 \\
1.3\end{array}$} & \multirow{3}{*}{1} & 1 & 0,05 & 0,056 & 1,9 & 2,30 \\
\hline & & 5 & 0,055 & 0,059 & 2,2 & 2,47 \\
\hline & & 7 & 0,06 & 0,061 & 2,5 & 2,62 \\
\hline \multirow{3}{*}{$\begin{array}{l}2.1 \\
2.2 \\
2.3\end{array}$} & \multirow{3}{*}{5} & 1 & 0,08 & 0,084 & 3,7 & 3,96 \\
\hline & & 2 & 0,09 & 0,085 & 4,2 & 4,06 \\
\hline & & 7 & 0,095 & 0,093 & 5,4 & 5,15 \\
\hline \multirow{3}{*}{$\begin{array}{l}3.1 \\
3.2 \\
3.3\end{array}$} & \multirow{3}{*}{9} & 2 & 0,11 & 0,114 & 6,3 & 6,49 \\
\hline & & 5 & 0,13 & 0,130 & 7,9 & 7,56 \\
\hline & & 10 & 0,17 & 0,166 & 9,3 & 9,09 \\
\hline \multirow{3}{*}{$\begin{array}{l}4.1 \\
4.2 \\
4.3\end{array}$} & \multirow{3}{*}{13} & 2 & 0,14 & 0,144 & 8,5 & 8,42 \\
\hline & & 5 & 0,17 & 0,167 & 9 & 8,94 \\
\hline & & 7 & 0,19 & 0,178 & 9,5 & 9,21 \\
\hline \multirow{3}{*}{$\begin{array}{l}5.1 \\
5.2 \\
5.3\end{array}$} & \multirow{3}{*}{20} & 5 & 0,2 & 0,204 & 10,1 & 10,14 \\
\hline & & 7 & 0,21 & 0,208 & 10,2 & 10,20 \\
\hline & & 10 & 0,22 & 0,216 & 10,4 & 10,34 \\
\hline \multirow{3}{*}{$\begin{array}{l}6.1 \\
6.2 \\
6.3\end{array}$} & \multirow{3}{*}{30} & 7 & 0,22 & 0,222 & 10,8 & 10,84 \\
\hline & & 10 & 0,23 & 0,227 & 11 & 10,95 \\
\hline & & 20 & 0,24 & 0,239 & 11,8 & 11,79 \\
\hline
\end{tabular}




\begin{tabular}{|c|c|c|c|c|c|c|}
\hline \multirow{3}{*}{$\begin{array}{l}\text { Level } \\
\left(\mathrm{N}^{\circ}\right)\end{array}$} & \multicolumn{2}{|c|}{ Machining conditions } & \multicolumn{4}{|c|}{ Machining quality performance } \\
\hline & \multirow{2}{*}{$\begin{array}{l}\text { Discharge } \\
\text { current } \\
I(\mathrm{~A})\end{array}$} & \multirow{2}{*}{$\begin{array}{l}\text { Pulse duration } \\
T(\mu \mathrm{s})\end{array}$} & \multicolumn{2}{|c|}{ Gap distance } & \multicolumn{2}{|c|}{ Surface roughness } \\
\hline & & & $a_{E X P}(\mathrm{~mm})$ & $a_{F I S}(\mathrm{~mm})$ & $R_{a E X P}(\mu \mathrm{m})$ & $R_{a} F I S(\mu \mathrm{m})$ \\
\hline 7.1 & \multirow{3}{*}{50} & 10 & 0,25 & 0,250 & 12 & 12,00 \\
\hline 7.2 & & 20 & 0,28 & 0,279 & 12,4 & 12,39 \\
\hline 7.3 & & 100 & 0,31 & 0,310 & 13,7 & 13,70 \\
\hline \multicolumn{7}{|c|}{ Test data } \\
\hline 1. & 1 & 2 & 0,05 & 0,06 & 2 & 2,27 \\
\hline 2. & 5 & 5 & 0,095 & 0,094 & 5 & 4,78 \\
\hline 3. & 9 & 7 & 0,15 & 0,132 & 8,8 & 8,75 \\
\hline 4. & 13 & 10 & 0,2 & 0,165 & 9,9 & 9,69 \\
\hline 5. & 20 & 20 & 0,23 & 0,215 & 11,1 & 11,3 \\
\hline 6. & 30 & 50 & 0,25 & 0,24 & 12,3 & 11,8 \\
\hline 7. & 50 & 50 & 0,3 & 0,28 & 13,2 & 12,5 \\
\hline \multicolumn{3}{|c|}{ Average error: } & \multicolumn{2}{|l|}{$6,13 \%$} & \multicolumn{2}{|l|}{$4,54 \%$} \\
\hline
\end{tabular}

By comparing the model data and experimental results, the average deviation of the FIS model is $6.13 \%$ and $4.54 \%$ for the gap distance and surface roughness, respectively.

Graphic design of the FIS modeling of the relationship between machining quality performance and electrical discharge parameters can be seen in Figure 5.

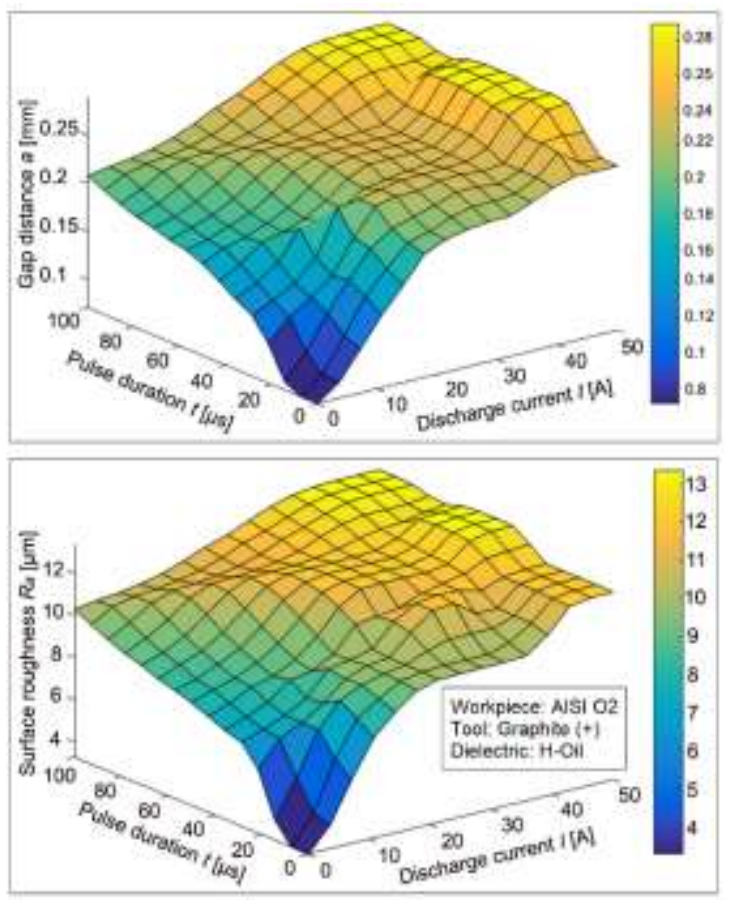

Figure 5 - FIS modeling of gap distance and surface roughness in EDM process

The diagrams show that the increase of the discharge current as well as the pulse duration results in a uniform increase of the gap distance and surface roughness. Besides, from this three-dimensional shape it is very easy to see the effect of the EDM input variables on the output quality.For the purpose of assessment of the FIS structure, the model data is compared with that of the experimental results. Test simulations were carried out and statistical validation were used for determining the performance of the proposed FIS model. In this comparison, the experiments were divided into two groups, one for training (21 experiments in 7 levels) and another for testing (7 experiments with one from each level).
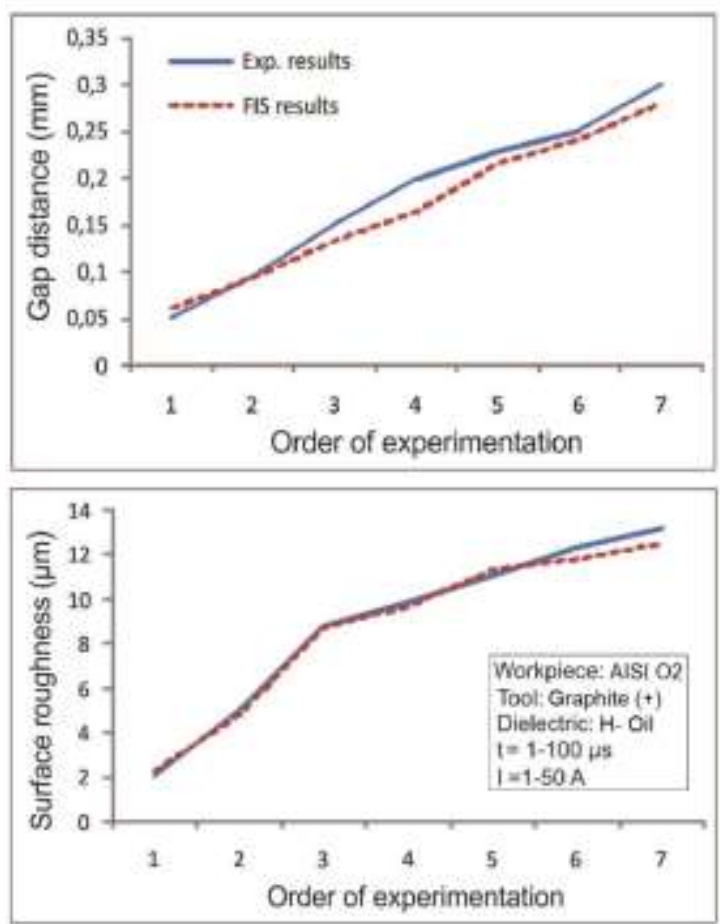

Figure 6 - Comparison of predicted FIS results with the experimental data of the gap distance and surface roughness 
According to the assessment results, the proposed FIS method is efficient for estimating the machining quality performance in EDM process. Figure 6 depicts the comparison of experimental results and FIS model predictions for the gap distance and surface roughness. The lines of experiment and FIS seem to be close to each other indicating a high degree of accuracy.

\section{DISCUSSION}

In according with the results shown in the previous chapter, it indicated that the FIS method used in this research is feasible and could be used to predict the EDM machining quality with an acceptable error rate. Figure 7 presents the relationships between the gap distance and surface roughness.

The diagram shows a high correlation between parameters of machining quality, concretely the geometrical accuracy and surface finish of EDM machined components. This proves that obtained results presented that the FIS model provides comprehensive prediction of the EDM process.

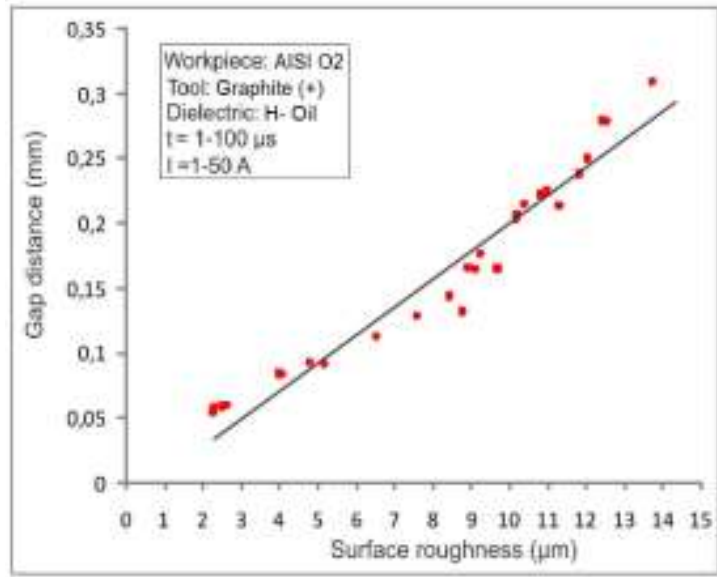

Figure 7 - The relationship of the parameter of machining quality

Firstly, based on experimental investigation it was established that machining quality of EDM directly depends on the machining conditions. As can be seen, the dimensional accuracy and surface finish of EDM predominantly depend on the electrical discharge parameters, which in practice can be changed by the discharge current and pulse duration.

On the other hand, the fuzzy inference system which established the influence of the discharge current and pulse duration on machining quality in EDM was experimentally verified. The obtained investigation results certainly confirm high concord of experimental research and FIS structure.

In this context, this paper has successfully established the fuzzy inference mechanism for predicting the machining quality of the workpiece. The FIS model can be viewed as a system that maps an input variables to an output performance, respectively gives the influence of the discharge current and pulse duration on the EDM machining quality. In this way it has been established a fuzzy inference model which gives some good information which could be used in further researches for the optimal control of EDM process.

\section{CONCLUSION}

The estimation of the machining quality performance in electrical discharge machining is very important in the manufacturing of a wide range of products. Fuzzy inference system based modeling of the electrical discharge machining quality was used in this paper.

This approach was based on experimental results, where the input parameters are discharge current and pulse duration, while the output are electrode gap distance and surface roughness of the high alloy cold work tool steel during EDM. Comparison of the data sets of the FIS simulation with experimental values have shown that the average errors of the gap distance and surface roughness have gone down to $6,13 \%$ and $4.54 \%$, respectively.

Also, the FIS model has shown that the machining quality in EDM is changing with the increase of discharge current and pulse duration. In this context, the conducted study shows that the proposed FIS model is very efficient for prediction and optimal control of the electrical discharge machining quality.

\section{ACKNOWLEDGMENTS}

The paper is the result of the research within the project financed by the Ministry of Science and Technological Development of the Republic of Serbia.

\section{REFERENCES}

[1] Rao R. V, Advanced modeling and optimization of manufacturing processes, Springer, London, 2011.

[2] Kovac P, Gostimirovic M, Sekulic M, Savkovic B, A review of research related to advancing manufacturing technology, Journal of Production Engineering, Vol. 12, No. 1, pp. 9-16, 2009.

[3] Tesić S, Zeljković M, Čiča D, Optimizacija i ispitivanje uticaja parametara rezanja na hrapavost obrađene površine pri glodanju biokompatibilne legure - Ti6Al4V, Tehnika, Vol. 74, No. 5, pp. 677682, 2019.

[4] Konig W. Fertigungsverfahren, Band 3 Abtragen, VDIVerlag GmbH, Dusseldorf, Germany, 1979.

[5] Zhang Q. H, Zhang J. H, Ren S. F, Niu Z. W, A theoretical model of surface roughness in ultrasonic vibration assisted electrical discharge machining in 
gas, International Journal of Manufacturing Technology and Management, Vol. 7, pp. 381-390, 2005.

[1] Salman O, Kayacan M. C, Evolutionary programming method for modeling the EDM parameters for roughness, Journal of Materials Processing Technology, Vol. 200, pp. 347-355, 2008.

[2] Gostimirovic M, Kovac P, Sekulic M, An inverse optimal control problem in the electrical discharge machining, Sadhana, Vol. 43, No. 5, ID 70, 2018.

[3] Tsai K. M, Wang P. J, Comparisons of neural network models on material removal rate in electrical discharge machining, Journal of Materials Processing Technology, Vol. 117, pp. 111-124, 2001.

[4] Gostimirovic M, Radovanovic M, Madic M, Rodic $\mathrm{D}$, Kulundzic N, Inverse electro-thermal analysis of the material removal mechanism in electrical discharge machining, The International Journal of Advanced Manufacturing Technology, Vol. 97, No 58, pp. 1861-1871, 2018.

[5] Hanif M, Ahmad W, Hussain S, Jahanzaib M, Shan A. H, Investigating the effects of electric discharge machining parameters on material removal rate and surface roughness on AISI D2 steel using RSM-GRA integrated approach, The International Journal of Advanced Manufacturing Technology, Vol. 101, No. 5-8, pp. 1255-1265, 2019.

[6] Yilmaz O, Eyercioglu O, Gindy NZ. A user-friendly fuzzy-based system for the selection of electro discharge machining process parameters, Journal of Materials Processing Technology, Vol. 172, pp. 363371, 2006.

[7] Shabgard MR, Badamchizadeh MA, Ranjbary G, Amini K. Fuzzy approach to select machining parameters in electrical discharge machining (EDM) and ultrasonic-assisted EDM processes, Journal of Manufacturing Systems, Vol. 32, No. 1, pp. 32-39, 2013.

[8] Rodic D, Gostimirovic M, Madic M, Sekulic M, Aleksic A, Fuzzy model-based optimal energy control during the electrical discharge machining, Neural Computing \& Applications, 2020, doi: 10.1007/s00521- 020-04909-4.

[9] Tsai K. M, Wang PJ. Predictions on surface finish in electrical discharge machining based upon neural network models, International Journal of Machine Tools and Manufacture, Vol. 41, pp. 1385-1403, 2001.

[10]Lin J. L, Lin C. L. The use of grey-fuzzy logic for the optimization of the manufacturing process, Journal of Materials Processing Technology, Vol. 160, pp.914, 2005.

[11]Caydas U, Hascalik A, Ekici S, An adaptive neurofuzzy inference system (ANFIS) model for wireEDM, Expert Systems with Applications, Vol. 36, No. 2-3, pp. 6135-6139, 2009.

[12]Suganthi X. H, Natarajan U, Sathiyamurthy S, Chidambaram K. Prediction of quality responses in micro-EDM process using an adaptive neuro-fuzzy inference system (ANFIS) model, The International Journal of Advanced Manufacturing Technology, Vol. 68, No. 1-4, pp. 339-347, 2013.

[13]Gostimirovic M, Pucovsky V, Sekulic M, Radovanovic M, Madic M, Evolutionary multi-objective optimization of energy efficiency in electrical discharge machining, Journal of Mechanical Science and Technology, Vol. 32, No. 10, pp. 4775-4785, 2018.

[14]Klir G. J, Yuan B. Fuzzy sets and fuzzy logic: theory and applications, Prentice Hall PTR, New Jersey, 1995.

[15]Cojbasić Z, Brkić D, Veštačka neuronska mreža kao alat za procenu hidrauličkog otpora, Tehnika, Vol. 6, pp. 947-953, 2011.

[16]Rodic D, Sekulic M, Gostimirovic M, Pucovsky V, Kramar D. Fuzzy logic and sub-clustering approaches to predict main cutting force in highpressure jet assisted turning, Journal of Intelligent Manufacturing, 2020, doi: 10.1007/s10845-020-01555-4.

[17]Ross T. J, Fuzzy Logic with Engineering Applications, John Wiley \& Sons, New Jersey, 2010.

[18]Mamdani EH, Assilian S. An experiment in linguistic synthesis with a fuzzy logic controller, International Journal of Man-Machine Studies, Vol. 7, pp. 1-13, 1975.

[19]Sugeno M, Kang G. T, Structure identification of fuzzy model, Journal of Fuzzy Sets and Systems, Vol. 28, No. 1, pp. 15-33, 1988. . 


\section{REZIME}

\section{PREDVIĐANJE KVALITETA ELEKTROEROZIVNE OBRADE ZASNOVANO NA FAZI SISTEMU ZAKLJUČIVANJA}

Kvalitet i produktivnost su dve najvažnije performanse elektroerozivne obrade (EDM). U ovom radu predstavljena je primena fazi sistema zaključivanja (FIS) za predviđanje kvaliteta obrade kod EDM procesa. Konkretno, FIS je sproveo modeliranje geometrijske tačnosti $i$ završne obrade delova obrađenih sa EDM. Kod modela fazi sistema zaključivanja, ulazne promenljive su struja pražnjenja $i$ trajanje impulsa, a izlazni parametri su zazor između elektroda i hrapavost površine radnog komada. Postavka predloženog FIS modela omogućuje efikasniji izbor ulaznih vrednosti EDM procesa, što potom dovodi do boljih uslova obrade i izlaznog kvaliteta proizvoda. Modeliranje EDM procesa zasnovano na fazi sistemu zaključivanja je pokazalo vrlo dobre rezultate u poređenju sa eksperimentalnim podacima.

Ključne reči: EDM proces, parametri pražnjenja, zazor, hrapavost površine, FIS model 